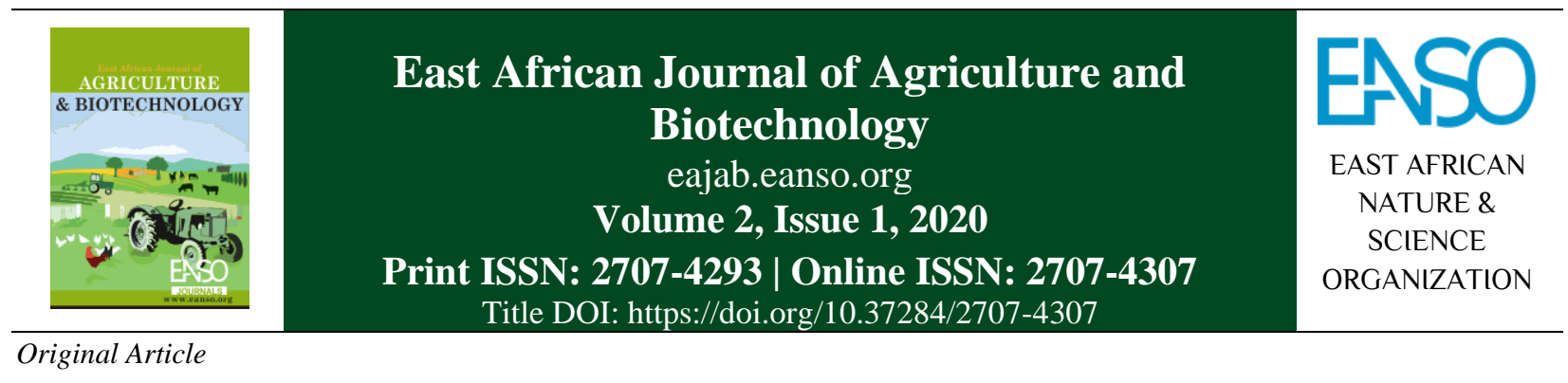

\title{
Agrowastes Potentials in Releasing Soil form of Nitrogen
}

Leye Samuel Ayeni*1, Ademola Isaac Agbona ${ }^{2}$ \& Oluwatoyin Peter Oso ${ }^{1}$

${ }^{1}$ Department of Agricultural Science, Adeyemi College of Education, Ondo, Ondo State Nigeria.

${ }^{2}$ Department of Agricultural Science, Federal Polytechnic, Ile-Oluji, Ondo State, Nigeria.

*Author for Correspondence email: leye_sam@yahoo.com

Article DOI: https://doi.org/10.37284/eajab.2.1.228

Date Published: ABSTRACT

27 October 2020 A laboratory incubation study to determine the decomposition rate of Sunflower (SF), Gliricidia sepium (GL), Kola Pod Husk (KPH), Keywords: and Cocoa Pod Husk (CPH) on soil forms of nitrogen was carried out at the Department of Agricultural Science, Adeyemi College of Education, Ondo South-Western Nigeria. The soil sample was collected from the farmers' field in Ondo. The soil was air-dried and sieved through a $2 \mathrm{~mm}$ diameter laboratory sieve. $200 \mathrm{~g}$ of the soil samples were weighed into cups and $1 \mathrm{~g}$ of each CPH, SF, GL and KPH was added. The treatments were replicated five times to give 45 cups of soil samples and arranged on a Completely Randomised Design. The cups were covered with absorbents. The treatments were analysed 30,60 and 90 days to determine total $\mathrm{N}$, $\mathrm{NO}_{3}-\mathrm{N}$ and $\mathrm{NH}_{4}-\mathrm{N}$ using destructive analytical method. Compared with control, all the treatments significantly increased total $\mathrm{N}$ and $\mathrm{NO}_{3}-\mathrm{N}$ while SF and GL significantly increased $(\mathrm{p}<0.05) \mathrm{NH}_{4}-\mathrm{N}$ at 30 days of incubation. All the treatments significantly increased ( $\mathrm{p}<0.05$ ) total $\mathrm{N}, \mathrm{NH}_{4}-\mathrm{N}$ and $\mathrm{NO}_{3}-\mathrm{N}$ at 60 and 90 days. Cocoa Pod Husk had the highest increase in total $\mathrm{N}$ while $\mathrm{KPH}$ recorded the highest $\mathrm{NH}_{4}-\mathrm{N}$ and $\mathrm{NO}_{3}-\mathrm{N}$. Cocoa Pod Husk (CPH), KPH, GL and $\mathrm{SF}$ could be used to increase soil forms of $\mathrm{N}$ for optimum crop production in Ondo, South-Western Nigeria. 


\section{CHICAGO CITATION}

Ayeni, Leye, Ademola Agbona, and Oluwatosin Oso. 2020. "Agrowastes Potentials in Releasing Soil form of Nitrogen”. East African Journal of Agriculture and Biotechnology 2 (1), 51-57. https://doi.org/10.37284/eajab.2.1.228.

HARVARD CITATION

Ayeni, L., Agbona, A. and Oso, O. (2020) “Agrowastes Potentials in Releasing Soil form of Nitrogen”, East African Journal of Agriculture and Biotechnology, 2(1), pp. 51-57. doi: 10.37284/eajab.2.1.228.

\section{IEEE CITATION}

L. Ayeni, A. Agbona, and O. Oso, “Agrowastes Potentials in Releasing Soil form of Nitrogen”, EAJAB, vol. 2, no. 1, pp. 51-57, Oct. 2020.

\section{MLA CITATION}

Ayeni, Leye, Ademola Agbona, and Oluwatosin Oso. "Agrowastes Potentials in Releasing Soil form of Nitrogen". East African Journal of Agriculture and Biotechnology, Vol. 2, no. 1, Oct. 2020, pp. 51-57, doi:10.37284/eajab.2.1.228.

\section{INTRODUCTION}

Nitrogen can be added to the soil through the application of inorganic nitrogenous fertilisers and organic fertilisers, such as animal and plant residues. Some agrowastes have been reported to have the tendency of releasing higher ammonium nitrogen and nitrogen nitrate used for crop production (Ayeni et al. 2015). Mineral fertilisers are very easy to use, but they have a detrimental effect of the soil at long use. Also, farmers must be cautious of the amount of nitrogen fertilisers they add to the soils because of their negative effects on the environment in generality and aquatic ecosystems. Excess nitrogen has a negative effect on plant growth and yield as well as drinkable water and water bodies. Excess $\mathrm{N}$ in water causes eutrophication and causes environmental pollution during burning by releasing poisonous nitrogen monoxide.

Farmers in southwestern Nigeria commonly use sunflower and gliricidia leaves as mulching materials while cocoa pod husk and kola pod husks are popularly used as organic fertilisers. Gliricidia plants are good as staking materials and are also used in silviculture. There is need to determine the rate at which nitrogen is released when cocoa pod husk, kola pod husk, sunflower and gliricidia are applied into the soil and the amount the organic wastes release to the soil to guide against their negative impacts on the soil and man. Research works have shown that the selected agrowastes are sources of plant nutrients (Ayeni et al., 2008; Titiloye et al., 1985; Wallace, 1994 and Odedina et al., 2007). The objective of this study was to determine the rate of nitrogen mineralisation by cocoa pod husk, kola pod husk, sunflower and gliricidia in Ondo Southwestern Nigeria.

\section{MATERIALS AND METHODS}

The laboratory incubation study to determine the rate of $\mathrm{N}$ mineralisation from cocoa pod husk, gliricidia and sunflower were conducted in the laboratory of Agricultural Science Department of Adeyemi College of Education, Ondo, in 2016. The soil sample was collected from the Adeyemi College of Education Teaching and Research Farm. The soil samples were then air-dried and sieved through a $2 \mathrm{~mm}$ diameter mesh. The experimental design was Completely Randomised Designed and replicated nine times.200g of air-dried soil sample was weighed into forty-five different plastic cups and labelled according to the treatment applied. The treatments applied were 
0 and $1 \mathrm{~g}$ to represent 0 and $10 \mathrm{t} /$ ha respectively were weighed into the plastic cups. An equal volume of water was added to the content of each container. The samples were then incubated for three months. Three months was assumed to be the maturity period for most arable crops in South-Western Nigeria. A descriptive-analytical method was used to determine the rate of mineralisation of the selected agrowastes at 30,60 and 90 days of incubation.

\section{Soil Nutrient Determination and Data Analysis}

Soil $\mathrm{pH}$ was determined using a glass electrode $\mathrm{pH}$ meter in 1.2 soil-water ratios $10 \mathrm{~g}$ of the soil sample was weighed into $100 \mathrm{ml}$ beaker (in duplicate) and $20 \mathrm{ml}$ of distilled water was added. Each beaker was stirred several times for about 30minutes. The $\mathrm{pH}$ of the sample was measured by immersing the glass electrode into a clear solution on top of the suspension.

Total nitrogen $(\mathrm{N})$ was determined by MicroKjedahl method NH4-N and NO3-H by steam distillation technique of Bremner and Keeney (1966). Available Phosphorus (P) was extracted by Bray-1- method and determined colourimetrically. Exchange bases ( $\mathrm{K}, \mathrm{Ca}, \mathrm{Mg}$ and $\mathrm{Na}$ ) were extracted with neutral ammonium acetate. Calcium (Ca), magnesium $(\mathrm{Mg})$, potassium $(\mathrm{K})$ and sodium $(\mathrm{Na})$ were determined from the filtrate by atomic absorption spectrophotometer (AAS). Organic carbon was determined by Walkey Black wet oxidation method.

Data collected were subjected to analysis of variance (ANOVA) and separated by the least significant difference.

\section{RESULT AND DISCUSSION}

Table 1 shows the soil properties before the experiment was conducted. According to Ayeni (2012), the soil was neutral to slightly alkaline, low in organic matter with adequate nitrogen level. The soil was high in available $\mathrm{K}$.

Table 1: Initial Soil Chemical Properties

\begin{tabular}{ll}
\hline Soil Properties & Values \\
\hline Textural Class & Sandy \\
$\mathrm{Ph}$ & 7.20 \\
$\mathrm{OC} \%$ & 0.40 \\
$\mathrm{~N}(\%)$ & 0.12 \\
$\mathrm{P}\left(\mathrm{mg} \mathrm{kg}^{-1}\right)$ & 31.00 \\
$\mathrm{~K}(\mathrm{C} \mathrm{mol} \mathrm{kg}$ & 0.24 \\
$\left.\mathrm{Ca}(\mathrm{C} \mathrm{mol} \mathrm{kg})^{-1}\right)$ & 22.16 \\
$\mathrm{Mg}(\mathrm{C} \mathrm{mol} \mathrm{kg}$ & 1.05 \\
\hline
\end{tabular}

\section{Chemical Composition of SF, GL, KPH and CPH}

Table 2 shows that the chemical analysis of the content of plant nutrients in sunflower, gliricidia, kola pod husk and cocoa pod husk. This is in agreement with the work of Partey et al. (2011), Kumar and Mishra (2013), Ayeni et al., (2015), Makinde et al. (2013) and Adeosun et al. (2013) that sunflower, gliricidia, kola pod husk and cocoa pod husk contain N, P, K, Ca and $\mathrm{Mg}$ that could be used to increase soil nutrients. Partey et al. (2011) worked on gliricidia and sunflower and observed that they contain low $\mathrm{C} / \mathrm{N}$ ratios that enhance early nutrients such as $\mathrm{N}$ mineralisation. AduDapaah et al., (1994), Adeoye et al., (2001) and Odedina et al. (2011) reported that cocoa pod husks are being used as fertilisers and soil amendments to suppress nematode population in cocoa soil because of its high $\mathrm{K}$ content. 
Obatolu (1995) reported the use of cocoa pod husk as fertiliser for coffee and maize production.

Table 2: Nutrient Composition of Agrowastes

\begin{tabular}{llllllll}
\hline Treatments & OC & N & C/N & P & K & Ca & Mg \\
\hline SF & 12.86 & 1.28 & 10 & 0.15 & 2.53 & 1.29 & 5.00 \\
GL & 42.31 & 3.80 & 11 & 0.32 & 6.79 & 1.30 & 4.79 \\
KPH & 22.80 & 1.49 & 15.00 & 0.26 & 3.93 & 6.90 & 3.80 \\
CPH & 17.56 & 1.23 & 14.00 & 0.21 & 6.52 & 3.74 & 2.40 \\
Lsd (0.05) & & & & & & \\
\hline NB: SF - Sunflower, GL - Gliricidia, KPH - Kola Pod Husk, CPH - Cocoa Pod Husk
\end{tabular}

\section{Effect of Selected Organic Wastes on Forms of Nitrogen}

Table 3 shows the total $\mathrm{N}, \mathrm{NO}_{3}-\mathrm{N}$ and $\mathrm{NH} 4-\mathrm{N}$ mineralisation capacity of Gliricidia (GL), Sunflower (SF), Kola Pod Husk (KPH) and Cocoa Pod Husk (CPH) after 30 days of incubation. Compared with control, SF, GL, $\mathrm{KPH}$ and $\mathrm{CPH}$ significantly increased (p $<0.05)$ total $\mathrm{N}, \mathrm{NO}_{3}-\mathrm{N}$ and $\mathrm{NH}_{4}-\mathrm{N}$ compared with control, all the treatments significantly increased total $\mathrm{N}$ and $\mathrm{NO}_{3}-\mathrm{N}$ while $\mathrm{SF}$ and GL significantly increased $(\mathrm{p}<0.05) \mathrm{NH}_{4}-\mathrm{N}$ at 30 days of incubation. Cocoa Pod Husk (CPH) recorded the highest total $\mathrm{N}$ among the treatments. Sunflower (SF) recorded the highest amount of $\mathrm{NH}^{-}{ }^{-} \mathrm{N}$, while $\mathrm{KPH}$ recorded the highest amount of $\mathrm{NO}_{3}-\mathrm{N}$. The amount of $\mathrm{NH}_{4}-\mathrm{N}$ and $\mathrm{NO}_{3}-\mathrm{N}$ mineralised by $\mathrm{SF}$, GL, $\mathrm{KPH}$ and $\mathrm{CPH}$ was sufficient optimum crop production in South Western Nigeria where this experiment was conducted (Ayeni, 2012).

Table 3: Rate of nitrogen mineralization organic wastes after 30 days of incubation

\begin{tabular}{llll}
\hline Treatment & Total $\mathbf{N}(\mathrm{mg} / \mathrm{kg})$ & $\mathbf{N H} \mathbf{4}(\mathrm{mg} / \mathrm{kg})$ & $\mathbf{N O}-\mathbf{N}(\mathrm{mg} / \mathrm{kg})$ \\
\hline Control & 139.30 & 26.07 & 19.50 \\
SF & 366.78 & 58.16 & 13.95 \\
GL & 206.56 & 45.5 & 26.28 \\
KPH & 323.74 & 28.18 & 38.83 \\
CPH & 385.55 & 24.28 & 32.51 \\
Lsd $(0.05)$ & 11.23 & 4.54 & 4.23 \\
\hline
\end{tabular}

The rate of nitrogen mineralisation of Sunflower, Gliricidia sepium, Kola Pod Husk and Cocoa Pod Husk after 60 days of incubation is shown in Table 4. Compared with control, all the treatments significantly increased $(\mathrm{p}<0.05)$ total $\mathrm{N}, \mathrm{NH} 4-\mathrm{N}$ and $\mathrm{NO}_{3-}$
$\mathrm{N}$ at 60 days of incubation. Kola Pod Husk had the highest GL. The soil samples treated with $\mathrm{KPH}$ recorded the highest NH4-N, followed by $\mathrm{CPH}$. Application of 10t/ha of KPH had the highest significant $\mathrm{NO}_{3}-\mathrm{N}$ release rate followed by $\mathrm{CPH}$. 
East African Journal of Agriculture and Biotechnology, Volume 2, Issue 1, 2020

Article DOI: https://doi.org/10.37284/eajab.2.1.228

Table 4: Rate of nitrogen mineralisation by organic wastes after 60 days of incubation

\begin{tabular}{llll}
\hline Treatment & Total $\mathbf{~}(\mathbf{m g} / \mathbf{k g})$ & $\mathbf{N H 4}-\mathbf{N}(\mathbf{m g} / \mathbf{k g})$ & $\mathbf{N O}-\mathbf{N}(\mathbf{m g} / \mathbf{k g})$ \\
\hline Control & 49.3 & 20.07 & 17.62 \\
SF & 61.82 & 25.98 & 19.93 \\
GL & 89.76 & 33.63 & 26.27 \\
KPH & 178.21 & 55.86 & 38.86 \\
CPH & 91.47 & 39.47 & 32.25 \\
Lsd $(0.05)$ & 10.13 & 5.61 & 6.91 \\
\hline
\end{tabular}

The rate of mineralisation of total $\mathrm{N}, \mathrm{NH}_{4}-\mathrm{N}$ and $\mathrm{NO}_{3}-\mathrm{N}$ by Sunflower, Gliricidia sepium, Kola Pod Husk and Cocoa Pod Husk is shown in Table 5. Compared with control, SF, GL, $\mathrm{KPH}$ and $\mathrm{CPH}$ significantly increased $(\mathrm{P}<0.05)$ total $\mathrm{N}$ and $\mathrm{NO}_{3}-\mathrm{N}$ while $\mathrm{KPH}$ significantly increased NH4-N among the treatments, $\mathrm{CPH}$ recorded the highest increase in total $\mathrm{N}$ followed by $\mathrm{KPH}$. The order of increase in $\mathrm{NH}_{4}-\mathrm{N}$ mineralisation was $\mathrm{KPH}>\mathrm{CPH}>\mathrm{GL}>$ $\mathrm{SF}>$ control. The order of mineralisation of $\mathrm{NO}_{3}-\mathrm{N}$ by the treatments were $\mathrm{KPH}>\mathrm{CPH}>$ GL> SF control.

Table 5: Rate of nitrogen mineralisation by organic wastes after 90 days of incubation

\begin{tabular}{llll}
\hline Treatment & Total $\mathbf{N}$ & NH4-N & NO3-N \\
\hline Control & 40.01 & 21.09 & 17.62 \\
SF & 68.72 & 22.67 & 14.41 \\
GL & 49.06 & 31.99 & 21.87 \\
KPH & 56.51 & 48.73 & 30.59 \\
CPH & 70.41 & 38.26 & 28.34 \\
Lsd $(0.05)$ & 8.59 & 7.27 & 8.34 \\
\hline
\end{tabular}

\section{CONCLUSION}

The objective of this experiment was to determine the rate of nitrogen mineralisation by Cocoa Pod Husk (CPH), Kola Pod Husk (KPH), Sunflower (SF) and Gliricidia (GL) in the soil. The result obtained shows that the soil used for the experiment was neutral to slightly alkaline, low in organic matter and in micronutrients such as $\mathrm{Cu}, \mathrm{Zn}$ and $\mathrm{Mn}$. Cocoa Pod Husk (CPH), Kola Pod Husk (KPH), Sunflower (SF) and Gliricidia (GL) has a reasonable amount of nutrient. After 30 days of incubation $(\mathrm{CPH})$ recorded the highest total $\mathrm{N}$, $\mathrm{SF}$ recorded the highest amount of NH4-N while $\mathrm{KPH}$ recorded the highest amount of $\mathrm{NO}_{3}-\mathrm{N}$. After 60 days, KPH has the highest increase in total $\mathrm{N}$ followed by $(\mathrm{CPH})$ and (GL). (KPH) recorded the highest amount of NH4-N followed by CPH. After 90 days, $\mathrm{CPH}$ recorded the highest increase in total $\mathrm{N}$ followed by $(\mathrm{KPH})$. (KPH) recorded the highest amount of NH4-N followed by $\mathrm{CPH}$ then GL. The experiment conducted to show the decomposition rate of Cocoa Pod Husk, Kola Pod Husk, Sunflower and Gliricidia on 
soil forms of nitrogen, has shown that the agrowastes could be used to increase soil $\mathrm{N}$ in South-Western Nigeria.

\section{REFERENCES}

Adeosun, S., Adejobi, K., Famaye, A., Idrisu, M., Ugioro, O., \& Nduka, B. (2013). The combined effect of kola testa based organic manure and NPK fertiliser on soil, leaf chemical composition and growth performance of kola (Cola nitida). Res. J. Agric. Environ. Management, 2(7), 183189.

Adeoye, G. O., Sridhar, M. K. C., \& Ipinmoroti, R. R. (2001). Potassium recovery from farm wastes for crop growth. Communications in soil science and plant analysis, 32(15-16), 2347-2358.

Adu-Dapaah, H. K., Cobbina, J., \& Asare, E. O. (1994). Effect of cocoa pod ash on the growth of maize.The Journal of Agricultural Science, 122(1), 31-33.

Ayeni, L. S. (2012). Combined effect of cattle dung and urea fertiliser on organic carbon, forms of nitrogen and available phosphorus in selected Nigerian soils. Journal of Central European Agriculture, 13(3), 601607.

Ayeni, L. S., Adetunji, M. T., Ojeniyi, S. O., Ewulo, B. S., \& Adeyemo, A. J. (2008). Comparative and cumulative effect of cocoa pod husk ash and poultry manure on soil and maise nutrient contents and yield. American-Eurasian Journal of Sustainable Agriculture, 2(1), 92-97.

Ayeni, L. S., Mutiu, S., Sunday, O. \& Ali, K. (2015). Laboratory experiment on soil nutrients mineralisation and interaction as affected by cocoa pod husk, kola pod husk and urea fertiliser in alfisol. American Journal of Agricultural Science, 2(4), 144149

Bray, R. H., \& Kurtz, L. T. (1945). Determination of total, organic, and available forms of phosphorus in soils. Soil science, 59(1), 39-46.

Bremner, J. M., \& Keeney, D. R. (1966). Determination and isotope-ratio analysis of different forms of nitrogen in soils: 3 . Exchangeable ammonium, nitrate, and nitrite by extraction-distillation methods. Soil Science Society of America Journal, 30(5), 577-582.

Kumar, P., \& Mishra, P. K. Cultivation of Gliricidia sepium (Gliricidia) and its use for improving soil fertility. Journal of the Kalash Science, 1(1), 131 - 133.

Makinde, E. A., Ipinmoroti, R. R., Iremiren, G. O., \& Ayeni, L. S. (2013). Utilization of kola pod husk for Telfaria occidentalis, Corchorus olitorius and Amaranthus cruentus production in Ikorodu, Lagos State. Res. Rev: J. Bot. Sci, 2, 9-13.

Obatolu, C.R. (1995). Nutrient Balance Sheet after Coffee and Maize Cropping on Alfisol Supplied with Organic Fertilisers in Ibadan, Nigeria. Proceeding of 3rd all Africa Soil Science Society held at Ibadan between August 20-23, 1995, 250-256.

Odedina, J. N., Odedina, S. A., \& Ojeniyi, S. O. (2011). Effect of types of manure on growth and yield of cassava (Manihot esculenta, Crantz). Researcher, 3(5), 1-8. 
Odedina, S. O., Awodun, M., \& Ojeniyi, S. O. (2007). Effect of cocoa husk on the soil fertility, leaf mineral composition and growth of tomatoes. Globa. Jour. Environ. Studies, 26(1), 6-12.

Partey, S. T., Quashie-Sam, S. J., Thevathasan, N. V., \& Gordon, A. M. (2011). Decomposition and nutrient release patterns of the leaf biomass of the wild sunflower (Tithonia diversifolia): a comparative study with four leguminous agroforestry species. Agroforestry Systems, 81(2), 123-134.

Titiloye, E. O., Lucas, E. O., \& Agboola, A. A. (1985). Evaluation of fertiliser value of organic waste materials in South-Western Nigeria.Biological Agriculture \& Horticulture, 3(1), 25-37.

Wallance, A. (1994). Soil Organic Matter as Essential Material. Solving Environmental Problems Com. Soil Science and Plant Analysis, 25, 1-2. 